\title{
Variations of Interest Among People for Watching Cricket with Respect to Blood Grouping
}

\author{
Muhammad Imran Qadir and Arslan Hassan* \\ Institute of Molecular Biology and Biotechnology, Multan, Pakistan
}

*Corresponding author: Arslan Hassan, Institute of Molecular Biology and Biotechnology, Multan, Pakistan

Received Date: June 20, 2019

Published Date: July 02, 2019

\begin{abstract}
The objective of present study was to corelate blood grouping with people's interests in watching cricket. There are four principle types: $\mathrm{A}, \mathrm{B}, \mathrm{AB}$, and $\mathrm{O}$. Two antigen and two antibodies that are mostly answerable for the $\mathrm{ABO}$ forms and A.B.O blood kinds are controlled by a gene by three sorts of allele indirect since traditional inheritances $\mathrm{i}, \mathrm{I}^{\mathrm{A}}, \mathrm{I}^{\mathrm{B}}$. The gene stays positioned on the extensive arm of ninth chromosomes (9c34). The $\mathrm{I}^{\mathrm{A}}$ allele give blood type $\mathrm{A}$ and ${ }^{\mathrm{IB}}$ springs form $\mathrm{B}$ and I give form $\mathrm{O}$. By way of together $\mathrm{I}^{\mathrm{A}} \mathrm{I}^{\mathrm{B}}$ are dominants on $\mathrm{I}$. ii are of blood group $\mathrm{O}$. It was concluded from present study that mostly people of $\mathrm{B}^{+}$blood group take no interest in cricket watching and people of $\mathrm{O}^{+}$blood group are cricket watching lovers.
\end{abstract}

Keywords: Blood grouping; Watching cricket; Sharp container

\section{Introduction}

Landsteiner discovered them while checking blood transfusion cause for death why. Four type of blood group $\mathrm{O}$ AB A and B are due to the results of two antigen and two antibodies and A.B.O blood kinds are controlled by a gene by three sorts of allele indirect since traditional inheritances: $\mathrm{I}^{\mathrm{A}} \mathrm{I}^{\mathrm{B}}$. A genetic factor positioned in lengthy arms of 9th chromosomes(9c34) the $\mathrm{I}^{\mathrm{A}}$ spring category A and I B springs category B i give form 0 . By way of together $\mathrm{I}^{\mathrm{A}}$ $\mathrm{I}^{\mathrm{B}}$ dominating on I individual ii gives 0 type blood. Persons by $\mathrm{I}^{\mathrm{A}}$ $\mathrm{I}^{\mathrm{B}}$ take two phenotype for having $\mathrm{A}, \mathrm{B}$ direct superior domination association: Co-dominances: the meaning is the nature $\mathrm{A}$ and $\mathrm{B}$ parent will take kid of blood group AB. A combine by form A and $B$ can possess form 0 kid if parents are Heterozygous. They both are differ in their pH optima at 5.6 for $\mathrm{A} 1$ and 7-8 foe $\mathrm{A}_{2}$ and so the activity $A_{1}$ is higher and also higher isoelectric point than $A_{2}$ enzymes. The $\mathrm{H}$ alleles, expressed as the homozygotes $(\mathrm{HH})$ or heterozygote $(\mathrm{Hh})$, produces $\mathrm{H}$ transferases. This enzyme adds single terminal carbohydrates molecule, L-Fucose, to the substance and this additional sugar moiety converts the precursor substance to $\mathrm{H}$ antigens. The $\mathrm{A}$ and $\mathrm{B}$ genes via their enzymes products each add a terminal carbohydrates molecule to $\mathrm{H}$ thus converting it to A to $\mathrm{B}$ in which A transferases improve $\mathrm{N}$-acetyl-D-Galactosamines toward $\mathrm{H}$, and B transferase enhances D - Galactoses toward H. The gene product is an enzymes $\mathrm{A}$ or $\mathrm{B}$ transferase which require the $\mathrm{H}$ antigen in order to act. This means the ABO genetic pathway also dependent on inheritance of the $\mathrm{H}$ gene of $\mathrm{H}$ blood group system. if the $\mathrm{A}$ allele is present $\mathrm{A}$ transferase act on $\mathrm{H}$ antigen to produce an antigen and if the $B$ is present then $B$ transferase act on $\mathrm{H}$ antigen to produce the $\mathrm{B}$ antigen because these alleles are the codominant. ABO antigens do not show dosage as seen for some other blood group antigens for example group A red cell produces by the homozygote AA genotype do not react more strongly with anti A than Group A red cells of the heterozygote AO genotype [1].

Cricket was first played in 16th century in south east England and developed in country at nationwide level in eighteenth century then advanced internationally in the 19th and 20th century Cricket is on 2nd place in popularity after football. Cricket is played in almost whole world areas, observed and respected via lots. Cricket can be played by all types of people either they are small or large and of all ages it keeps person active Its rules are simple and easy so mostly people love cricket and love to play. Cricket has a 2.5 billion fans estimated global following and its prime sphere of influence is in the U.K and commonwealth countries. The sport is overwhelmingly popular in the former British colonies such as India, Srilanka, Bangladesh, and Pakistan Almost everyone has 
their own best player and take him as model for him and follow him at everywhere in fields, in social media and even his walking and talking styles. To watch a cricket match, it continuous, fans would take a day off from work. Some fans are forever remained attached with own teams but there is another sort of admirer is fair-Weather fan. They always tease people without any superiority to other player by admiring his favorite player

The objective of present study was to corelate blood grouping with interest in watching Cricket.

\section{Material and Method}

\section{Method}

While taking a blood sample we must take care of some important things we must have all our supplies including needle, strap, liquor wipes, handbags, tubes for putting blood sample and a carrier for putting samples of blood full tubes. Before taking sample, you should introduce to patient. Put on your gloves then apply tourniquet on mid-upper arm. Formerly checkered to vein for forced arm vein drive similar to trampolines sensations. Fresh wound place via liquor cloth just twenty seconds. Applying the needle on skin that isn't taunt causes pain, then remove needle and cap the needle then smear tags on tubes and remove the strap and hygiene used things and put them in the vessel and gave blood sample for further testing. Blood typing is technique for telling that which blood group is running in your veins. Blood type is depending upon the certain protein named as antigens. The sample of blood needed. The test for blood group determination is named as blood typing of ABO blood. The sample of blood is assorted with antibodies for A and B blood. At that time the sample of blood is checked that either blood cells stick together or not. If antibodies react then cells sticks to each other otherwise not. Individuals having group A anti-b antibodies and B blood group has anti-a antibody. The $\mathrm{O}$ blood group has both antibodies. The Rh typing of blood have same principle for $\mathrm{ABO}$ grouping of blood. The results are simple if $\mathrm{Rh}$ factor present on the red blood surfaces then $\mathrm{Rh}^{+}$ otherwise $\mathrm{Rh}$ :

\section{Project Design}

First of all, we took the blood sample of the subjects and checked the blood group of all by above mention method. Then we made a list of subjects with their blood group type and consented them one by one that whether they take interest in watching cricket or not. They told us their interests about watching cricket and we wrote on the list with their blood group type whether they love to watch cricket or not. Total 168 subjects participated in this study. Subjects were students of Bahauddin Zakariya University Multan, Pakistan.

\section{Statistical Analysis}

Statistical analysis was performed by using Microsoft Excel.

\section{Results and Discussion}

(Table 1) There was no scientist or searcher who worked on the variation of interest among people for watching cricket with respect to blood grouping. Variations of interest among people for cricket with respect to blood grouping is given in table 1 . From table 1 people having blood group $\mathrm{B}^{+}$mostly take less interest in watching cricket and people having blood group $\mathrm{O}^{+}$mostly take interest in watching cricket than other blood groups people. Questionnaire based studies have been given important outcomes in current researches [3-10].

Table 1: Variation of interest among people for watching cricket with respect to blood grouping.

\begin{tabular}{|c|c|c|c|c|c|c|}
\hline \multirow{2}{*}{$\begin{array}{l}\text { Not interested in } \\
\text { Watching Cricket }\end{array}$} & \multicolumn{2}{|c|}{ Interested in Watching cricket } & \multicolumn{2}{|c|}{ Not interested in Watching Cricket } & \multirow[t]{2}{*}{ Total Yes \% } & \multirow[t]{2}{*}{ Total No \% } \\
\hline & Male & Female & Male & Female & & \\
\hline $\mathrm{A}^{+}$ & $6.54 \%$ & $7.14 \%$ & $0.59 \%$ & $2.97 \%$ & $13.68 \%$ & $3.56 \%$ \\
\hline $\mathrm{A}^{-}$ & $0.59 \%$ & $0 \%$ & $0 \%$ & $0 \%$ & $0.59 \%$ & $0 \%$ \\
\hline $\mathrm{B}^{+}$ & $5.35 \%$ & $0.59 \%$ & $17.85 \%$ & $11.90 \%$ & $5.94 \%$ & $29.75 \%$ \\
\hline B- & $1.19 \%$ & $1.19 \%$ & $0 \%$ & $0.59 \%$ & $2.38 \%$ & $0.59 \%$ \\
\hline $\mathrm{AB}^{+}$ & $1.78 \%$ & $2.97 \%$ & $0 \%$ & $1.78 \%$ & $4.75 \%$ & $1.78 \%$ \\
\hline $\mathrm{AB}^{-}$ & $0 \%$ & $0.59 \%$ & $0 \%$ & $0 \%$ & $0.59 \%$ & $0 \%$ \\
\hline $0+$ & $7.14 \%$ & $13.09 \%$ & $2.38 \%$ & $8.33 \%$ & $20.23 \%$ & $10.71 \%$ \\
\hline O- & $0 \%$ & $2.38 \%$ & $0 \%$ & $2.97 \%$ & $2.38 \%$ & $2.97 \%$ \\
\hline
\end{tabular}

\section{Conclusion}

It was concluded from present study that mostly males of $\mathrm{B}^{+}$ blood group take less interest in watching cricket and females with $\mathrm{O}^{+}$blood group were interested in watching cricket.

\section{Acknowledgment}

None.

\section{Conflicts of Interest}

No conflicts of interest.

\section{References}

1. Qadir MI, Malik SA (2010) Comparison of alterations in red blood cell count and alterations in hemoglobin concentration in patients suffering from rectal carcinoma undergoing 5-fluorouracil and folic acid therapy. Pharmacologyonline, Nl 3: 240-243.

2. Qadir MI, Noor A (2018) Anemias. Rare \& Uncommon Diseases. Cambridge Scholars Publishing. Newcastle, England. ISBN: 978-1-52751807-0.

3. Qadir MI, Javid A (2018) Awareness about Crohn's Disease in biotechnology students. Glo Adv Res J Med Medical Sci 7(3): 062-064.

4. Qadir MI, Saleem A (2018) Awareness about ischemic heart disease in university biotechnology students. Glo Adv Res J Med Medical Sci 7(3): 059-061. 
5. Qadir MI, Ishfaq S (2018) Awareness about hypertension in biology students. Int J Mod Pharma Res 7(2): 08-10.

6. Qadir MI, Mehwish (2018) Awareness about psoriasis disease. Int J Mod Pharma Res 7(2): 17-18.

7. Qadir MI, Shahzad R (2018) Awareness about obesity in postgraduate students of biotechnology. Int J Mod Pharma Res 7(2): 14-16.
8. Qadir MI, Rizvi M (2018) Awareness about thalassemia in post graduate students. MOJ Lymphology \& Phlebology, 2(1): 14-16.

9. Qadir MI, Ghalia BA (2018) Awareness survey about colorectal cancer in students of M. Phil Biotechnology at Bahauddin Zakariya University, Multan, Pakistan. Nov Appro in Can Study 1(3): NACS.000514.2018.

10. Qadir MI, Saba G (2018) Awareness about intestinal cancer in university student. Nov Appro in Can Study 1(3): NACS.000515.2018. 